\title{
MORAL VALUES IN EDUCATION: TEACHING ENGLISH CLASSROOM AT MA'HAD TAHFIZUL QUR'AN RAHMATULLAH SAMARINDA
}

\author{
Ariyanti \\ Widya Gama Mahakam University \\ ariyanti.muflihin@gmail.com
}

\begin{abstract}
It is obvious that moral values are values which always represent our daily lives. They reflect our activities wherever we are in society such as at school, at home, etc. In this article, the researcher tries to investigate the moral values directly to educational world by having the guideline of components of educational moral values proposed by Veugelers. This research is a descriptive qualitative study where the researcher describes in a very detail information regarding with what moral values reflected in English classroom at Ma'had Tahfizul Qur'an Rahmatullah Samarinda. As a result, the researcher found that from five components of educational moral values, there are only one component which is Moral Politics which seldom appears during the teaching and learning process. In addition, the components of Value Transfer, Reflective Practitioner, Moral Sensitivity, and Dialogue and Participant appear in the most meetings in the classroom. From those findings, it can be concluded that the participant, where in this case is the English subject teacher, cares about the teaching of moral values to the students in the classroom by transferring good moral attitudes, having the students to be sensitive and responsible individuals, as well as facilitate the students to have group discussion and work in pairs to solve their problems in learning English together.
\end{abstract}

Keywords: Moral Values, Education, Teaching English Classroom

\section{INTRODUCTION}

It is obvious that moral values are important aspects in human life since it represents what happen in society individually or in group. Many experts and researchers state that moral values are important aspects at school that one of them is Ma (2009) who says that Educators in Chinese society regards moral values in education as the most important where some essential concept of moral values and moral education become major issues and being discussed among educators. That is why investigating the concept of moral values becomes the first step before going to its relationship to education.

The morality itself is a view of being good and bad or right and wrong based on certain set of norms and principles. Generally, morality grouped into respect, responsibility, integrity, and honesty (Kaur, 2015). Moreover, Kaur also adds that the actions which 
contained with morality are related to social situation where people should use their skills of reasoning, problem solving, and self control to adapt with phenomenon happened in society.

The concept of moral values is still general where it points out about compassion, justice, truth, and forgiveness or what so called by Golden Rule (Kinnier, Kernes, \& Dautheribes, 2000)(Kinnier et al., 2000). There are four basic identifications in the Golden Rule, they are (a) respect for oneself, (b) respect for others, (c) civic responsibility, and (d) respect for natural environment. Based on those moral values identification, what comes to be an interesting fact is they can be used or applied in school curriculum and also counseling (Hanley, 1989).

In line with theory of Henley above, Veugelers (2008) also points out that "values are embedded in the curriculum, the school culture and the behaviour of the teacher". Regarding with this matter, it is not merely about whether the teacher applies the moral values in education but tend to the point of what values the teacher practices in the classroom. Usually, moral values regard as hidden aspects since they reflect abstract elements such as justice, respect, honesty, etc. In fact, if the teacher tries to apply a certain element, consciously it will influence the development of the students.

In particular, above theory indicates that moral values are important to be existed in students' development. As Roy (2013) explores about the importance of moral values in students' live that it is vital for teacher to apply an appropriate method to teach the students about morality because it is potential for the teacher to be blamed by society if the students misbehaves such as telling lies or unrespect to others. However, the students always observe their teacher at school especially when the teacher is teaching in the classroom. They are the truly master of imitating of what their teacher does especially for those who are still in the category of kids. Teacher' attitudes and behaviours can have an effect on the students' actions because the teacher the important role model for his students (Joseph \& Efron, 2005; Ornstein \& Hunkins, 1998; Pajaras, 1992). Concequently, the teacher should set himself as a model and be aware of doing wrong behaviour in front of the students.

Surprisingly, there was Ten Life Education Project in Hong Kong which is supported by Quality Education Fund (QEF) which consider the combining aspects between life and ethics and teaching. There are three main educational objectives which proposed in the project, firstly the curriculum as a whole is aimed to help the students develop based on their characteristics. Secondly, the process of teaching and learning should be formed in happy and different situation in order not to avoid the boredom of the students. In this case, the teacher

Script Journal Volume 1, Issue 1, April 2016 || ISSN 2477-1880 || E-ISSN 2502-6623 http://jurnal.fkip-uwgm.ac.id/index.php/Script 
needs to make interactive activities to attract and dig the students' creativities and ideas. Lastly, the result is hopefully can produce the intended outcome which is the students' positive development (Ma, 2009).

To the more particular points to assess in Ten Life Education Project is that there are eight important domains including moral, intellectual, physical, social, aesthetic, sex, emotion, and environmental education which are briefly explained as follows (Ma, 2009):

1. Programs for moral education emphases on fostering honesty, rule and law-abiding orientation and justice judgment.

2. Programs for intellectual education focuses on learning skills and creative thinking.

3. Programs for physical education focuses on physical development, the meaning of life, aging, sickness and death.

4. Programs for social education deal with issues relating to human relationships, and national and racial identity.

5. Programs for aesthetic education focus on cultivating an ability to appreciate beauty in daily life.

6. Programs for sex education focus on sex difference, sex-role development, and sexuality and love.

7. Programs for emotion education attempt to teach students skills to cope with stress, facing unpleasant interaction and overcoming difficulties in daily life.

8. Programs for nature (environment) education emphasize on helping students to understand and appreciate the beauty of nature.

Furthermore, moral education is such an eternal goal of education because school is not only responsible for producing an intellectual student but also a good person in terms of attitudes and behaviours. In this case, formal schools from any level always deal with how to influence the way the students think, feel, and act regarding with two main universal items which are right and wrong (Kaur, 2015).

Focusing to the main aspect of this research content, it is very important to highlight moral values in teaching in the classroom. In this case, Veugelers (2008) proposes five moral values in teaching, they are:

1. Value Transfer

Script Journal Volume 1, Issue 1, April 2016 || ISSN 2477-1880 || E-ISSN 2502-6623

http://jurnal.fkip-uwgm.ac.id/index.php/Script 
This value focuses on the moral educational transfer. It is regarding with good attitudes that can support good behaviour of the students. In this part, the teacher also tries to teach the students on how to deal with multicultural and changing society with various religions in an open-minded position.

\section{Reflective Practitioner}

This value is dealing with how the teacher can teach the students to reflect the moral values through action. In this case, the students also should take responsibility on their behaviour.

3. Moral Sensitivity

Concerning with this of moral values, the teacher can form a dialogue to the students and ask the students to explain why they choose certain ideas and practices. It is only involving moral reasoning on the sensitivity of the teacher when moral values are involved or at stake.

4. Participation and Dialogue

This part, of course, dealing with how the teacher get the students involved in dialogic activities or communication actions to reconstruct and challenge their ideas as well as participation through classroom activities designed by the teacher. In other words, the teacher becomes a facilitator in the classroom so the students can relate between dialogic activity and an action through classroom participation.

\section{Moral Politics}

Morality according to this part is embedded in a political context. It means that the aim of education is in the form of political action for social change such as the use of the concept of teaching to change the world and teaching for social justice.

\section{METHODOLOGY}

In this research, the researcher uses qualitative method because the main intension of the study is to explain and explore very rich information about focus of the research. As Patton (1990) points out that "qualitative methods typically produce a wealth of detailed information about a much smaller number of people and cases." In addition, the researcher displays the data found in the form of a table and the detail description of educational moral values reflected in the teaching and learning process of English subject. 
Related to the subject of the study, there are two levels provided in Ma'had Tahfizul Qur'an Rahmatullah Samarinda, they are Ula level (the same as Elementary school level) and wustho level (the same as Junior High school level). In this research, the researcher only observes an English teacher who teaches at wustho level. Since the researcher is eager to focus on teaching Engish classroom, the researcher does not focus on observing teachers who teach in Ula level because they are simply the teachers who teach all of the subjects learned in the classroom. That is why the researcher decides to observe only an English teacher who teach in the first, second, and third grade of Wusho level.

Furthermore, the researcher herself becomes the key instrument in this research as it is one of qualitative research characteristics (Patton, 1990). Moreover, the researcher also investigastes moral values in relation to the teachers' perspective in using them in teaching in the classroom where it considers as a natural phenomenon in qualitative research.

Related to the researcher's observation, the researcher comes to the classroom to observe the process of teaching and learning English directly to have a clear image of what moral values reflected in the classroom. This research is a participant observation where the according to Gay et al. (2006), there are two function of participant observation, they are "to observe the activities, people, and physical aspects of a situation and to engage in activities that are appropriate to a given situation and that provide useful information". In this case, the researcher acts as a passive observer where she seems to be a visitor and observe what is going on during the teaching and learning process in the classroom (Gay et al., 2006). In addition, the researcher brings the basic of moral values in teaching proposed by Veugelers (2008) in a piece of paper in each meeting complete with field notes to capture every single phenomenon happened during the teaching and learning process.

As this research is qualitative study, the researcher also uses standardized open-ended interview, to collect the data. Patton (1990) says that the standardized open-ended interview is the interview which consists of a set of questions which have already arranged in order to have the answer meets the objective of the study. Moreover, the interview guideline has been set and consisted of 10 questions regarding with moral values in teaching.

To the more particular to data collecting techniques, there are three kinds of data collecting techniques which proposed by Patton (1990), they are in-dept, open-ended interview, direct observation, and written document. Particularly in this research, the data obtained from interview is the form of the direct quotation of the subject's feelings, experiences, opinions, and knowledge regarding with moral values in teaching. Next, the data 
obtained from direct observation is in the form of description of the subject's behaviours, activities, and actions towards in teaching and learning process in the classroom. Furthermore, the researcher does not use the third technique since the researcher does not use any questionnaire or any other written document to investigate.

In addition, it is very important for the researcher to have the procedures on collecting the data in the form of clear steps. Those steps are:

1. The researcher comes to Madrasah Salafiyah Rahmatullah and meets the principle to ask for permission to do the research.

2. The researcher asks the schedule so that the researcher will be able to know when to meet the English teacher to do the interview and direct observation.

3. The researcher meets the English teacher to state her intension on having a research as well as conduct the interview regarding moral values in teaching.

4. The researcher records the interview so that she does not miss information needed.

5. The researcher comes to the classroom to get the direct and clear image of what happen during the teaching and learning process in the classroom.

6. The researcher finds the best seat and starts to observe the class as well as having the moral values in teaching theory proposed by Veugelers (2008) in the form of checklist.

7. The researcher write the field notes concerning with moral values reflected in the teaching and learning process and tries to capture all of the phenomenon happened especially regarding with moral values in the classroom.

In addition, it is highly important for the researcher to present how she analyse the data collected. In analyzing the data, the researcher uses the theory proposed by Creswell (1998) which is known as The Data Analysis Spiral that is explained briefly as follows:

1. Data managing

Data management is the first step in analyzing the data finding where in this part, the researcher should organize the data into file folders or computer files. After that, the researcher begins to convert the file into words or sentences.

2. Reading and memoing

After managing the data, the researcher has to write memos which is possible to present in terms of memoing the transcription, field notes, or interview data.

3. Describing, classifying, and interpreting

Script Journal Volume 1, Issue 1, April 2016 || ISSN 2477-1880 || E-ISSN 2502-6623

http://jurnal.fkip-uwgm.ac.id/index.php/Script 
In this part, the researcher should describe the data found in detail, classify and only take the data which is appropriate for the objective of the research as well as interpret the data with her and another person's point of view.

4. Representing and visualizing

In this part, the researcher formulates the visual presentation of the data in the form of text, tables, or figures.

\section{FINDING}

\section{Data Gained From Direct Observation}

Below table is the data findings of educational moral values which the researcher found during the direct observation. Check $(\sqrt{ })$ sign indicates kinds of moral values reflected in the classrooms.

\begin{tabular}{|c|c|c|c|c|c|c|}
\hline \multirow[b]{2}{*}{ Class } & \multirow[b]{2}{*}{ Meeting } & \multicolumn{5}{|c|}{ Educational Moral Values } \\
\hline & & $\begin{array}{c}\text { Value } \\
\text { Transfer }\end{array}$ & $\begin{array}{c}\text { Reflective } \\
\text { Practitioner }\end{array}$ & $\begin{array}{c}\text { Moral } \\
\text { Sensitivity }\end{array}$ & $\begin{array}{l}\text { Participation } \\
\text { and Dialogue }\end{array}$ & $\begin{array}{c}\text { Moral } \\
\text { Politics }\end{array}$ \\
\hline \multirow{4}{*}{ VII } & 1 & $\sqrt{ }$ & $\sqrt{ }$ & -1 & $\sqrt{ }$ & \\
\hline & 2 & $\sqrt{ }$ & $\sqrt{ }$ & $\sqrt{ }$ & $\sqrt{ }$ & \\
\hline & 3 & $\sqrt{ }$ & $\sqrt{ }$ & $\sqrt{ }$ & $\sqrt{ }$ & \\
\hline & 4 & $\sqrt{ }$ & $\sqrt{ }$ & $\sqrt{ }$ & $\sqrt{ }$ & \\
\hline \multirow{4}{*}{ VIII } & 1 & $\sqrt{ }$ & $\sqrt{ }$ & $\sqrt{ }$ & $\sqrt{ }$ & \\
\hline & 2 & $\sqrt{ }$ & $\sqrt{ }$ & $\sqrt{ }$ & $\sqrt{ }$ & \\
\hline & 3 & $\sqrt{ }$ & $\sqrt{ }$ & $\sqrt{ }$ & & \\
\hline & 4 & $\sqrt{ }$ & $\sqrt{ }$ & $\sqrt{ }$ & $\sqrt{ }$ & \\
\hline \multirow{3}{*}{ IX } & 1 & $\sqrt{ }$ & $\sqrt{ }$ & $\sqrt{ }$ & & $\sqrt{ }$ \\
\hline & 2 & $\sqrt{ }$ & $\sqrt{ }$ & $\sqrt{ }$ & & $\sqrt{ }$ \\
\hline & 3 & $\sqrt{ }$ & $\sqrt{ }$ & $\sqrt{ }$ & & $\sqrt{ }$ \\
\hline
\end{tabular}

Table 1 Educational Moral Values Reflected in Teaching English Classrooms

\section{Class VII}

At class VII, the English subject is taught on every Tuesday at 09.00-10.30. In this case, the researcher needs four times to observe the situation in classroom. On the first meeting on 22 March 2016, the researcher found that there are three educational moral value elements exist in the teaching and learning process, they are Value Transfer, Reflected Practitioner, and Participation and Dialogue. Value Transfer aspect is done by the teacher where she seems to deliver moral education to the students by being a good model for them in the classroom. The teacher acts and speaks in a very appropriate and polite way to make the students understand the material. Furthermore, the act of the teacher also reflects what so 
called by Reflective Practitioner by teaching to the students on how to responsible to their behaviour such as asking for forgiveness to their friends because of unpleasant attitudes. The next educational moral value which is reflected on the first meeting is Participation and Dialogue. In this part, the teacher provides a classroom discussion activity so that the students in a group can help each other.

On the second meeting on 29 March 2016, the researcher found four aspects of moral value in education, they are Value Transfer, Reflective Practitioner, Moral Sensitivity, and Participation and Dialogue. On that meeting, the researcher also found the same moral value aspects as the first meeting. In addition to the second meeting, the researcher found one additional moral value aspect which is Moral Sensitivity. As on the first meeting, the teacher also transfers moral value to the students by telling them that they should be open-minded individuals to accept differences among friends in the class. Moreover, Reflective practitioner is showed by the act of teacher to ask one students to apologize to another student because because of making her cries. In Participation and Dialogue aspect, the teacher asks the students to do task in pairs. In this case, the teacher facilitates the students to socialize and solve a problem together. Lastly, the teacher shows her sensitivity when several students act with a good morality in the classroom. In this case, the teacher is appreciating them by saying "good".

Lastly on the third meeting on 5 April 2016 and the fourth meeting on 12 April 2016, the researcher found the same moral values as on the second meeting, they are Value Transfer, Reflective Practitioner, Moral Sensitivity, and Participation and Dialogue. In this case, the researcher decides to stop the observation on the fourth meeting because the data saturation is already appeared three times from the second until the fourth meeting. Moreover, the activities conducted by the teacher in the classroom are typically the same.

\section{Class VIII}

At class VIII, the researcher spent four times to observe the teaching and learning process in the classroom where the English subject is learned on every Tuesday at 10.4512.15. On the first meeting on 22 March 2016 and the second meeting on 29 March 2016, the researcher found there are the same kinds of moral values in education, they are Value Transfer, Reflective Practitioner, Participation and Dialogue, and Moral Sensitivity. On these two meetings, the teacher acts in a good behaviour by speaking politely to the students. Next, the teacher teaches the students on how to act with good morality by asking them to be individuals who have high attention to responsibility on what they have done in the 
classroom. For example, as a representative of a group, the student is responsible to present the result of the group discussion to other students in the classroom. Meanwhile, other members of the group also have responsibility to help to answer questions from other groups when the representative cannot. In addition, through the group discussion, the teacher shows the act of being sensitive to moral action done by the students such as helping each other among the members of the groups or the condition where the representative of the members present the discussion materials in an appropriate way or not by giving comments to the groups in general.

On the third meeting on 5 April 2016, the researcher found three educational moral values they are Value Transfer, Reflective Practitioner, and Moral Sensitivity. The findings on the third meeting are kind of same as the first and the second meeting even though without the existing of Participation and Dialogue aspect. On the third meeting, the researcher found that the teacher represents the Value Transfer by supporting the students to do the best in doing a task given by the teacher as well as saying that they will correct the answers together and the teacher will explain about the answers to students to make everything clear. Reflective Practitioner is clearly showed when the students and the teacher do the correction activity through the task given. In this case, the teacher is sensitive enough to see and say to the students that if their answer is wrong so they should give a cross sign to the wrong numbers. It means that the teacher asks the students to be honest by not making their wrong answers to be the right one.

Lastly, the researcher decided to stop the observation at class VIII on the fourth meeting because the researcher found that there are four educational moral values which are the same as the first and the second meetings, they are Value Transfer, Reflective Practitioner, Moral Sensitivity, and Participation and Dialogue. In addition, the researcher found the activities which are not really different from the previous meetings.

\section{Class IX}

At the class IX, the English subject is learned on every Thursday at 09.00-10.30. At the class IX, the researcher spent three times to observe the educational moral values in the classroom. On the first meeting (24 March 2016), the second meeting (31 March 2016), and the third meeting (7 April 2016), the researcher found that there are the same educational moral values, they are Value Transfer, Reflective Practitioner, Moral Sensitivity, and Moral Politics. It is very interesting because since the researcher observe class VII and class VIII, the researcher did not find Moral Politics as the educational moral values reflected in the

Script Journal Volume 1, Issue 1, April 2016 || ISSN 2477-1880 || E-ISSN 2502-6623 http://jurnal.fkip-uwgm.ac.id/index.php/Script 
classrooms. It is different with class IX where Moral Politics aspect seems to be appeared three times in every meeting in the classroom. In this case, the researcher found that the researcher always try to give the students motivation to pass the National Examination and get high scores. Moreover, the teacher also says to the students that they can change and master everything in this world if only they have a good capability in English.

\section{Data Gained From Interview}

In order to get deeper data findings in this research, the researcher conducted interview to the subject of the researcher regarding with her feelings, experiences, opinions, and knowledge about moral values in education especially in teaching English subject in the classroom. The interview was conducted on Tuesday, 22 March 2016 and it ran very smoothly without any disturbance. Generally, the teacher can answer most of the questions which are appropriate to the researcher's objective. Firstly, concerning with the item of questions about the teacher's knowledge about moral values in general, the researcher asked about what moral values is as the first item of question, so she answers the question very fast by saying "Yes, of course. Emm.. Moral values are values which contain good things such as cares, honesty, and justice", but unfortunately the teacher cannot answer the second knowledge question when the researcher asked her concerning with components of educational moral values by saying "I don't know exactly".

Furthermore, the researcher asked her questions about her opinion whether teaching moral values important in the classroom as the item question number three, then she said " $I$ think it's important because living in this world without having good attitudes is useless. Specifically in educational world, the students are hoped to behave as good individuals to everyone such as to teachers and other students". In addition to the item question about opinion, the researcher asked to the teacher whether she think that she has played a role model of being a good teacher, then she answered it in certain by saying "I would say yes in $100 \%$. As a human being I have ever done many mistakes and unpleasant attitudes to other people or my students, but I always try to show everything in a good manner especially to my students. "In this term of question about opinion the teacher showed that she is so sure that teaching moral values in the classroom is important and she has given an example of being a good personality by acting in a good behaviour.

The next item of question which is asked by the researcher is about "feeling". In this case, the researcher asked to the teacher about her feeling about sensitivity to see whether the students perform attitudes which reflect moral values in the classroom. Through this question,

Script Journal Volume 1, Issue 1, April 2016 || ISSN 2477-1880 || E-ISSN 2502-6623 http://jurnal.fkip-uwgm.ac.id/index.php/Script 
the teacher said "I often pay attention to the students' behaviour in the classroom, may be not all the time, but emm. sometime I can see whether one student cares for his friend by showing an act of helping to each other, when one student has a conflict to another and they are mocking each other, or making the class so noisy, etc." In short, the researcher feels that she is sensitive enough to see the educational moral values involved in the classroom.

To the more particular questions in the interview session is item questions regarding with experiences. The item of "experiences" take the most frequent question to asked because it is the major elements to investigate by the researcher by knowing how the researcher reflect the components of educational moral values directly in the classroom. First of all, the researcher asked about the teacher's experiences in giving the students example of acting in a good behaviour in the classroom, then she said "I often pay attention to the classroom cleanness every time I come to their class to teach English. For example, I ask them to sweep the floor or clean the whiteboard, so on. In studying English in the classroom, since it is quite difficult to understand, I often have them work in pairs or in group discussion so that they can help each other." Next item of question about experience is the researcher asked to the teacher whether she asked the students to responsible towards their behaviour. In this case, the answer of the teacher is "Emm... Yes, once a student spoke impolite or rude to his friend in the classroom, then I asked him to apologize directly as well as asked him not to do that kind of behaviour in another time. " In addition to the experience question, the researcher also asked whether the teacher always get the students involved in activities which are related to moral values, then the teacher said "Of course, one of the activities is I teach them how to be sensitive individuals by caring each other".

To the more particular detail question about experience is the researcher asked the teacher whether she has ever facilitated the students to relate between dialogic activity and an action through classroom participation. Through this question, the teacher said "Yes, of course. Uh... I often get them involved in group discussion then I asked them to ask a question and respond toward the question in a very polite way and give clear explanation so that other students can understand". Lastly, the question about experience that the researcher asked is related to her experience in using moral values to teach moral politics such as social justice or how to change the world. For this question, the teacher said "Well, it is kind of difficult to answer and difficult question for a teacher. Maybe I can say that it is about motivation. Actually, I do it sometimes to make them serious in learning English, because if they master English well, they can have the world in their hands. Emm... They can travel 
wherever they want without being afraid of cannot communicate with people. Especially for the third grade, I usually motivate them to have high spirit in learning so that they can pass National Examination with good scores".

\section{DISCUSSION}

Based on the findings above, in his part, the researcher discusses the five components of educational moral values proposed by Veugelers (2008) related to the data gained from direct observation and interview. Firstly about Value Transfer as the first component of educational moral values, it is very interesting that the teacher always shows how she transfers the moral values in teaching English in the classroom by trying to be a good model for the students. In addition, she always speaks in appropriate way by explaining the material in a very clear and polite way to make the students understand the material. The act of transferring the moral values to the students by being a good example for her students, the teacher also teach the students to be open-minded individuals to accept differences among friends in the classroom.

Moreover, the next educational moral values which are Reflective Practitioner often happen in the process of teaching and learning in the classroom. For example, in correcting the task together in the class, the teacher asks the students to be honest by saying to the students that they should give cross if they have wrong answer. In addition, the teacher also teaches the students how to responsible to their behaviour. For instance, if one student makes mistakes such as mocking his friend or making his friend cries, so the teacher directly ask that student to apologize. In this component of educational moral value, the researcher also found several interesting facts that for example in a group discussion, the teacher asks the representative of each group to responsible to deliver the result of their discussion in very slow and clear words. Not only the representative of the group, the teacher also ask the other members to have responsibility in helping their friend to answer questions from the other groups.

To the more particular component of educational moral value which reflected in the classroom is Moral Sensitivity. Based on the data gained from interview, the teacher said that she is sensitive enough to see when moral value in terms of the students' action appear during the teaching and learning process. Fortunately, that fact is also showed by the action of teacher in teaching in the classroom. For example, after a group discussion finish, the teacher gives comment in general to all performances of the groups. In addition, the teacher 
sometimes appreciate the students who do good moral action in the class by saying "good" or "it is very kind of you".

Concerning with another educational moral value which is Participation and Dialogue, the teacher often makes group discussion or have the students work in pairs in order to make them helping each other because the teacher realizes that there are still many students who are lack of ability in understanding the material. In addition, when the teacher gave the students a task, then the teacher asked the students to switch their answer to their friend beside them and then they solve difficult questions together. Lastly, what the teacher understands about teaching moral politics is how the teacher give motivation to the students to study hard by saying English is important and by mastering it they do not have to be afraid to face what happen in the future when they grow adult. Besides, the teacher also gives the students of the third grade motivation to give the best in their National Examination.

\section{CONCLUSION}

Based on the findings and discussion which have been presented above, it can be concluded that the data gained from interview and direct observation in the classroom are mostly similar and match to each other. In other words, the teacher does what she has been said in the interview session such as being sensitive to the act of one student to another, often have the students work together in pairs or in a group discussion in order to solve their problem together regarding with the materials given by the teacher. In addition, it is kind of good fact that teacher never teaching the students without transferring the moral values to almost in every activity done in the classroom such as being a good model for the students by always trying to be polite in saying every single word to the students.

However, even though there are several activities which are seldom to do by the teacher such as the act of teaching to the students that they have to be open-minded people and accept the differences among their friends, the teacher always try to transfer good moral values especially in terms of real action. Moreover, the fact that the teacher always makes the students responsible towards their attitudes are always appeared in every meeting. In this case the researcher can conclude that the teacher feels that it is highly important for the students to have good morality and be responsible individuals in their lives.

To the more particular element which becomes the objective of the research, the researcher only found several activities contained with moral values which are related directly to the English materials. For instance, the act of working together in pairs or in a 
group makes the students eager to help each other and through the kind of discussion, the students can understand better than working alone. In addition, another fact which is found by the researcher is that the teacher wants the third grade students to pass the National Examination and also motivate the students from other classes to be serious in studying English because they will get so many advantages by mastering it. Lastly, the teacher also teaches the students to have honest personality when the students were asked by the teacher to not change their answer to the right one when they correct the answers of task given by the teacher together in the classroom

\section{BIBLIOGRAPHY}

Creswell, J. W. (1998). Qualitative Inquiry and Research Design: Choosing Among Five Traditions. Thousand Oaks, California: SAGE Publication Inc.

Gay, L. R., Mills, G. E., \& Airasian, P. (2006). Educational Research: Competencies for Analysis and Applications. Columbus: Pearson Merrill Prentice Hall.

Hanley, R. (1989, April). Keen Offers Plan to Teach 4 "Core Values" in School. The New York Times.

Joseph, P. B., \& Efron, S. (2005). Seven Worlds of Moral Education. Phi Delta Kappan, $86(7), 525-533$.

Kaur, S. (2015). Moral Values in Education. IOSR Journal of Humanities and Social Science, 20(3).

Kinnier, R. T., Kernes, J. L., \& Dautheribes, T. M. (2000). A Short List of Universal Moral Values. Issues and Insights. Counseling and Values, 45.

Ma, H.-K. (2009). Moral Development and Moral Education: An Integrated Approach. Hong Kong Educational Research Association, 24(2).

Ornstein, A. C., \& Hunkins, F. P. (1998). Curriculum: Foundations, Principles, and Issues (3rd ed.). Boston: Allyn and Bacon.

Pajaras, M. F. (1992). Teachers’ Beliefs and Educational Research: Cleaning Up a Messy Construct. Review of Educational Research, 62(3), 307-332.

Patton, M. Q. (1990). Qualitative Evaluatin and Research Methods (2nd ed.). California: SAGE Publication Inc.

Roy, S. (2013). Importance of Moral Values in Student Life. Retrieved March 24, 2016, from <http://www.importantindia.com/6898/importance-of-moral-values-in-student-life/

Veugelers, W. (2008). Moral Values in Teacher Education. In First Symposium on Moral and Democratic Education in Florina. Amsterdam: University of Amsterdam. 